CZU 316.6:343.91

https://doi.org/10.52507/2345-1106.2021-1.34

FACTORII INTEGRĂRII SOCIO-PROFESIONALE A EX-DEȚINUȚILOR

VÎRLAN Maria,

dr., conf. univ., decan facultatea Psihologie și PPS,

UPS "Ion Creangă”

\title{
REZUMAT
}

Integrarea socială a tinerilor delincvenți presupune mai multe componente: cultivarea încrederii în sine, restabilirea legăturii cu familia și menținerea acesteia, descoperirea şi încurajarea intereselor prosociale (ex. muncă, alfabetizare, educație, etc.), influența pozitivă a colegilor de muncă și a prietenilor dar și integrarea prin muncă.

Cuvinte-cheie: integrare socio-profesională, ex-deținuți, programe.

\section{FACTORS OF THE SOCIO-PROFESSIONAL INTEGRATION OF EX-PRISONERS}

VÎRLAN Maria

Dr., associate professor,

Dean of the Faculty of Psychology and PPS,

"Ion Creanga" State Pedagogical University 


\section{SUMMARY}

The social integration of young offenders involves several components: cultivating self-confidence, restoring and maintaining family ties, discovering and encouraging prosocial interests (eg. work, literacy, education, etc.), the positive influence of co-workers and friends but also integration through work.

Key-words: socio-professional integration, ex-prisoners, programs.

Integrarea socială trebuie raportată la specificul infracțiunii și la fiecare persoană în parte. Varietatea de infractiuni presupune o varietate de forme de reintegrare.

Problemele sociale cu care se confruntă persoanele aflate în conflict cu legea penală sunt similare cu ale altor grupuri vulnerabile, iar un răspuns eficient în rezolvarea unor astfel de probleme poate fi obținut doar printr-un efort comunitar integrat, care ia în considerare complexitatea problemelor sociale, interdependențele care există între acestea și suprapunerile care se creează între diferite grupuri vulnerabile $[1,5,12,13]$.

Sistemul penitenciar trebuie să sprijine reintegrarea socială a tuturor persoanelor private de libertate, pornind de la necesităţile individuale sociale, educaţionale şi terapeutice ale fiecărei persoane private de libertate și, mai ales.

Integrarea socioprofesională trebuie să se realizeze prin înlăturarea fenomenului de discriminare față de exdeținuți. Un alt obiectiv urmărit este de a încuraja dialogul şi colaborarea dintre angajatorii din spaţiul public şi privat, inclusiv reprezentanţi ai societăţii civile, pe marginea acestei probleme care priveşte societatea în mod direct [5].

Integrarea socială trebuie raportată la specificul infracţiunii şi la fiecare persoană în parte. Varietatea de infracţiuni presupune o varietate de forme de reintegrare.

Legislația califică infracţiunea, specialiștii în educaţie şi asistenţă psihosocială evaluează cauzele care au generat disfuncţionalităţile în cazul fiecărei persoane şi nici nu ar fi eficient să analizăm infracţiunea ca şi faptă.

Poate mai mult decât intervenția instituțiilor statului (ex. programe de reintegrare desfăşurate pe timpul executării pedepsei şi resursele materiale alocate acestor programe) contează sprijinul familiei şi mediul social [16].

Reintegrarea socială presupune şi reprimirea de către familie şi depinde de disponibilitatea familiei de a susţine material şi moral persoana condamnată. Menţinerea relaţiilor cu familia, iar acolo unde este cazul îmbunătățirea relaţiilor cu familia este un obiectiv prioritar pentru reinserţia socială a persoanei private de libertate.

În ce privește munca, pentru ca aceasta să fie eficientă în reintegrarea socială a persoanelor condamnate, trebuie ca şi acestea să fie interesate în munca respectivă şi nu doar în a câştiga o reducere a pedepsei cu închisoarea sau executarea unei sentințe în comunitate prin muncă în folosul comunităţii. Angajatorii cer seriozitate din partea angajatului şi de multe ori persoanele care au executat pedepse privative de libertate nu sunt motivate să muncească. În multe cazuri, persoanele care au executat pedepse privative de libertate preferă să lucreze pe piaţa neagră a muncii şi să fie beneficiari ai venitului minim garantat care le asigură şi acces la alte drepturi de asigurări sociale şi la hrana oferită prin cantinele sociale
[16].

Pentru angajatori este important şi felul în care persoana care a executat pedepse privative de libertate se poate integra în echipa de lucru (poate există stigmatizare din partea colegilor).

Integrarea prin muncă este o parte importantă a procesului, dar nu este singura.

Astfel, în reintegrarea socială a persoanelor care au fost condamnate penal pot fi eficiente:

$\square$ Cultivarea încrederii în sine;

$\square$ Menținerea legăturii cu familia;

$\square$ Descoperirea şi încurajarea intereselor prosociale (ex. muncă, alfabetizare, educaţie, etc.);

口 Influența pozitivă a colegilor de muncă şi a prietenilor.

Acestea sunt obiective ale activităţilor de educaţie şi de asistenţă psihosocială, utilizate de câțiva ani chiar [16].

Sistemul penitenciar sprijină reintegrarea socială a tuturor persoanelor private de libertate, pornind de la necesităţile individuale sociale, educaţionale şi terapeutice ale fiecărei persoane private de libertate şi, mai ales, nu sancţionează persoanele care după liberare nu au fost acceptate de comunitate şi au recidivat $[14,16]$.

Obiectivele principale ale programelor de reintegrare socială în comunitate a tinerilor delincvenți :

- protecţia comunităţilor locale prin acţiuni care vizează reducerea riscului de recidivă;

- justiţia socială, prin garantarea protecţiei şi echităţii sociale a tuturor părţilor (infractor, victimă, membrii comunităţii locale) implicate în rezolvarea conflictului generat de comiterea infracţiunii;

- punerea beneficiarilor intervenţiei în comunitate (infractori, familiile acestora, victime) în legătură cu resurse, într-o manieră care să îmbunătăţească imaginea de sine, asertivitatea, abilitatea de rezolvare a problemelor.

Cum pot fi atinse obiectivele programelor de reintegrare socială în comunitate:

- prin parteneriatul între instituţiile de stat (Judecătorii, şcoli, biserică, sindicate, instituții de sănătate, Poliție, Consiliul Local, Consiliul Raional, Agenţia de ocupare a forţei de muncă) şi organizaţii neguvernamentale;

- prin derularea unor programe de dezvoltare comunitară în scopul implicării partenerilor şi a membrilor comunităţii locale (voluntari, lideri) în:

- identificarea nevoilor comunităţii;

- găsirea soluţ̧iilor la problemele comunităţii locale;

- stimularea resurselor (colective, sociale) existente;

- atragerea şi crearea de noi resurse;

- dezvoltarea de noi servicii sociale.

- prin informarea şi sensibilizarea opiniei publice în legătură cu nevoile şi problemele comunităţii locale, 
nevoile şi problemele ex deţinuţilor şi a familiilor acestora şi cu modalităţile concrete de soluţionare a acestora (articole în presă, emisiuni radio, TV, conferinţe, întâlniri publice, etc.).

\section{Tehnici de intervenție în comunitate:}

- medierea (între persoana liberată şi familie, comunitate, reprezentanţi ai instituţiilor, etc.);

- negocierea ( metodele şi tehnicile folosite în programele de reintegrare se determină în funcţie de nevoile evaluate, de gradul de risc identificat, dar se şi negociază cu persoana liberată, în funcţie de priorităţile sale şi interesele sale);

- împuternicirea (ajutarea beneficiarilor de a se percepe ca fiind agenţi activi în găsirea soluţiilor la propriile probleme);

- advocacy (reprezentarea persoanelor liberate în faţa instituţiilor şi a reprezentanţilor autorităţilor din comunitate, precum şi exercitarea de presiuni prin mijloacele mass-media, publicaţii, etc., pentru ca acestea să sprijine procesul de reintegrare socială a exdeţinuţilor şi familiilor acestora) $[5,11]$.

Factori care favorizează angajarea persoanelor condamnate:

Șansele ca persoanele condamnate penal să fie angajate în câmpul muncii cresc dacă:

- Persoanele condamnate penal răspund nevoilor angajatorilor, în ce priveşte exigenţele legate de:

- Competenta reală şi calificarea profesională;

- Seriozitatea implicării în muncă (respectarea programului, productivitate, etc.).

- Persoana condamnată dovedeşte că are şi alte calităţi persoanele apreciate de angajator (dorinţa de a se integra, corectitudine, deschidere, punctualitate, seriozitate, etc.) ;

- Persoanele condamnate penal parcurg un proces de recrutare şi selecţie organizat şi desfăşurat de specialiştii în resurse umane. În acest fel se obţine o credibilitate crescută în legătură cu măsura în care persoana condamnată penal are calităţile profesionale şi potenţialul personal potrivite pentru ocuparea unei anumite poziţii;

- Există avantaje economice şi facilităţi fiscale pentru angajatori (altele decât productivitatea şi competenţa persoanelor condamnate): posibilitatea de a accesa fonduri nerambursabile, reduceri de taxe, salarii subvenţionate, etc. ;

- Muncitorii sunt supravegheați atent sau dacă cineva (ex. instituția penitenciară, probațiunea, serviciile sociale, ONG, în calitate de intermediari) garantează pentru ei;

- Angajatorii conştientizează şi se implică în acţiuni legate de responsabilitatea socială a firmelor ;

- Se construiesc parteneriate între angajatori şi instituţii ale sistemului de justiţie sau de protecţie socială, parteneriate de natură a facilita exprimarea responsabilităţii sociale a firmelor;

- Persoanele condamnate penal caută să se angajeze în posturi pentru ocuparea cărora nu este necesară prezentarea cazierului judiciar;

- Se realizează reabilitarea, iar faptele penale nu mai apar înscrise în cazier. Reabilitarea judecătorească presupune ca persoana care a fost condamnată penal să aibă un loc de muncă sau o sursă legală de venit, precum şi o bună conduită;

- Sunt popularizate experiențe pozitive şi cazuri de succes. În acest sens, trebuie menţionat că materialele informative sunt utile dar sunt considerate mai puţin eficiente decât întâlnirile sau atelierele de lucru cu potenţiali angajatori $\square$ Sunt aduse argumente de natură economică (ex. beneficii estimate în bani pentru comunitatea locală şi angajatorii care facilitează reintegrarea socială a foştilor infractori) şi sunt prezentate date statistice $[2,13]$.

Informarea angajatorilor şi întâlnirile directe ale acestora cu persoanele condamnate penal şi cu personalul serviciilor sociale, al serviciilor de probaţiune şi unităţilor penitenciare sunt factori importanţi în facilitarea asigurării de şanse egale la angajare pentru persoanele care execută o pedeapsă în comunitate sau care au încetat executarea unei pedepse.

Se pot organiza întâlniri între persoane condamnate penal şi potenţiali angajatori : „burse ale locurilor de muncă pentru persoanele condamnate penal", unde să aibă loc informarea şi selectarea angajatorilor, dar şi încurajarea persoanelor condamnate să caute un loc de muncă sunt acţiuni care au eficienţă în sensul facilitării integrării în muncă prin identificarea unor locuri de muncă disponibile pentru persoanele care au fost condamnate penal.

Experiența întâlnirilor organizate a arătat că:

- persoanele private de libertate aflate în perioada de pregătire pentru liberare pot beneficia în cea mai mare măsură de o astfel de acțiune;

- mobilizarea participării persoanelor condamnate sub supraveghere în comunitate este dificil de realizat, datorită faptului că personalul de probaţiune dispune de resurse şi de mijloace limitate pentru a putea influenţa şi controla activitatea persoanelor condamnate aflate în supraveghere în comunitate;

- că este posibilă, realistă şi de dorit implicarea în mai mare măsură a persoanelor private de libertate în activităţi în comunitate. Reprezentanţii serviciilor sociale din comunitate înţeleg necesitatea unor astfel de activităţi şi sunt dispuşi să le susţină;

- informarea mass-media şi a angajatorilor se poate face eficient atunci când la întâlnirile de informare participă şi persoane condamnate penal care pot relata aspecte concrete din experienţa lor de viaţă;

- desfãşurarea evenimentelor într-un mediu care oferă siguranţă şi încredere creşte şansele de formare a unor atitudini pozitive faţă de angajarea în muncă, atât pentru angajatori, cât şi pentru persoanele condamnate.

Printre factorii care favorizează implicarea angajatorilor se identifică:

- relațiile bune de colaborare stabilite între angajatori şi penitenciar;

- experienţa angajatorilor în lucrul cu persoanele condamnate penal,

- interesul angajatorilor în avantajele oferite de munca persoanelor condamnate penal (în condițiile în care forţa de muncă în anumite domenii este deficitară, angajatorii au apreciat posibilitatea de a utiliza forţa de muncă din penitenciare);

- interesul angajatorilor pentru implicarea socială a 
firmelor $[2,7,16]$.

Ținând seama de rezultatele acestor activități, se desprind următoarele recomandări:

- inițierea unor activități adresate angajatorilor şi cultivarea unor relaţii de colaborare între serviciile de probaţiune, serviciile sociale din comunitate, ONG implicate în reintegrarea socială a foştilor infractori şi potenţiali angajatori;

- dezvoltarea resurselor serviciilor de probațiune şi a măsurilor legale prin care acestea pot interveni pentru a determină şi controla activitatea persoanelor condamnate;

- o mai bună informare a angajatorilor în legătură cu beneficiile şi costurile sociale şi economice ale implicării în muncă a persoanelor condamnate penal;

- invitarea mass-media la acţiuni care au ca scop informarea publicului larg.

În cele ce urmează voi prezenta 2 modele de programe de integrare socială a ex-detinuților ce pot fi implementate în scopul prevenirii recidivei și responsabilizării beneficiarului.

\section{Program de consiliere de grup pentru} dezvoltarea competențele sociale şi emoţionale.

Programul de grup este axat pe următoarele tematici:

1. Cunoașterea propriei persoane;

2. Empatia;

3. Luarea deciziilor cu responsabilitate;

4. Eficienta socială.

\section{Cunoasterea propriei persoane:}

$>$ Identificarea ţi exprimarea propriilor emoţii şi sentimente;

$>$ Responsabilitate personală: Recunoaşterea și înţelegerea necesităţii de a se angaja în comportamente prosociale;

$>$ Recunoaşterea punctelor tari : Identificarea şi valorificarea propriilor calităţi pozitive.

\section{Empatia:}

> Preluarea perspectivei celorlalţi: Identificarea şi înţelegerea gândurilor/ sentimentelor celorlalți;

$>$ Acceptarea şi aprecierea diversităţii: Înţelegerea aspectelor pozitive a le diversităţii individuale şi culturale;

$>$ Respectarea celorlalți.

3. Luarea deciziilor cu responsabilitate:

> Managementul emoțiilor: Monitorizarea şi reglarea sentimentelor şi emoţiilor în aşa fel încât să-i ajute pe copii să se descurce în situații de viață diferite;

$>$ Analizarea situațiilor: Perceperea cu acuratețe a situațiilor în care trebuie luate decizii şi evaluarea factorilor care pot influența răspunsul unui individ.

$>$ Stabilirea scopurilor: Stabilirea scopurilor şi implicarea în atingerea acestora - scopuri prosociale pe termen scurt şi lung;

$>$ Rezolvarea

problemelor:

Generarea, implementarea şi evaluarea soluțiilor adecvate la problemele cu care se confruntă.

\section{Eficiența socială:}

$>$ Comunicare: Folosirea abilităţilor verbale şi nonverbale pentru a se exprima şi promovarea unor schimburi pozitive şi eficiente cu alții;

> Construirea relaţiilor: Stabilirea şi menţinerea unor relaţii care aduc satisfacţii;

> Negociere: Obținerea unor soluții convenabile pentru toate părţile implicate într-o relaţie ţinând cont de nevoile tuturor celor implicaţi;

$>$ Asertivitate: Exprimarea eficientă a deciziilor de a nu se angaja în comportamente antisociale;

$>$ Căutarea ajutorului: Identificarea nevoii de a apela la surse corespunzătoare de ajutor şi suport $[1,2,4,10,11]$.

\section{Campanii de informare „Bursa locurilor de muncă” pentru persoanele condamnate penal.}

Integrarea în activități de muncă a persoanelor care au fost condamnate penal. Conform experţilor, integrarea în muncă a persoanelor care au fost condamnate penal este unul dintre factorii principali care contribuie la creșterea siguranţei comunităţilor prin reducerea recidivei şi reintegrarea socială. Prin integrarea în muncă sau alte activităţi în comunitate, se exersează şi dezvolta abilități şi calificări profesionale, roluri şi responsabilităţi familiale şi sociale.

O mare parte dintre persoanele care execută sentinţe penale nu au o calificare şi au nevoie de facilitarea accesului la un nivel minim de educaţie care să le permită obținerea unei calificări.

Avantaje ale participării la muncă a persoanelor condamnate penal. Dacă persoanelor condamnate li se oferă posibilitatea de a se califica şi de a munci încă de la începutul executării sentinței, apar o serie de avantaje:

Avantaje pentru angajatori:

$\square$ În cazul angajării forţei de muncă din penitenciare, serviciile de resurse umane au mai puţin de lucru (selecţie de personal, plata impozitelor, administrarea cărţilor de muncă) şi deci costuri mai reduse. Se poate asigura astfel un bun raport preț / calitate pentru forţa de muncă;

$\square$ În cazul angajării forței de muncă din penitenciare, se realizează un bun control al costurilor: pentru că nu sunt încheiate contracte de muncă ci se face un contract cu penitenciarul pentru furnizare de forță de muncă, beneficiarul plătește $o$ factură care reprezintă contravaloarea exactă a orelor de muncă prestate efectiv;

$\square$ Forţa de muncă din penitenciare este sigură, stabilă, continuă. Muncitorii sunt conştiincioși, nu se pune problema absentei sau a părăsirii locului de muncă înainte de încheierea programului, nu sustrag materiale sau produse de la locul de muncă.

Avantaje pentru persoanele condamnate:

\section{Persoanele aflate în detenție:}

口 Se perfecționează, câştigă experiență şi chiar bani care le vor fi utili la liberare. Diplomele, certificatele sau orice alte documente care atestă însuşirea unei meserii, calificarea sau recalificarea profesională în cursul executării pedepsei sunt recunoscute, în condițiile legii;

$\square$ La liberare ştiu şi pot să facă gratuit diferite lucruri utile familiei şi în gospodărie, (reparaţii electrice, pus faianță, etc.);

¿ Faptul că lucrează pe timpul detenţiei poate fi o recomandare pozitivă şi ar trebui să aibă un impact pozitiv asupra încrederii comunităţii şi angajatorilor la liberarea din penitenciar ;

$\checkmark$ La punctele de lucru exterioare penitenciarului, 
deţinuţii: se pot acomoda cu viaţa în comunitate, dobândind şi exersând abilităţi şi cunoştinţe diferite de cele necesare supravieţuirii în mediul penitenciar o dobândesc experienţă şi cunoştinţe legate de integrarea într-un loc de muncă şi de relaţia cu angajatorul o pot folosi telefonul mobil şi bani (numai deţinuţii aflaţi în regimul deschis de detenţie);

$\square$ Reducerea pedepsei privative de libertate.

\section{Persoanele care execută sentințe în comunitate:}

$\square$ Se perfecționează, câștigă experiență şi bani care le sunt utili pentru întreținerea personală şi pentru susținerea familiei;

$\square$ Faptul că lucrează pe timpul executări pedepsei este o recomandare pozitivă şi are un impact pozitiv asupra încrederii comunităţii şi angajatorilor în cazul încercării de a găsi un loc de muncă mai bun;

$\square$ Prin implicarea în muncă exersează un stil de viaţă non-infracţional, dobândesc şi practică abilităţi şi cunoştinţe specifice unui comportament prosocial.

\section{Avantaje pentru penitenciar:}

$\square$ O parte din veniturile realizate pot fi folosite de penitenciar pentru îmbunătăţirea condiţiilor de detenţie şi a programelor de reintegrare socială;

$\square$ Personalul penitenciar are o satisfacţie crescută în muncă.

În continuare sunt prezentate câteva elemente utile în organizare unor activități de tipul ,, burselor locurilor de muncă pentru persoanele condamnate penal":

\section{Principii.}

$\square$ promovarea şi apărarea drepturilor unei categorii vulnerabile de populaţie (persoanele condamnate penal aflate în căutarea unui loc de muncă);

$\square$ asigurarea integrării şi incluziunii sociale, a demnităţii umane şi accesului egal la bunuri şi servicii publice;

$\square$ promovarea respectării prevederilor legale care guvernează încadrarea în muncă.

\section{Scop.}

$\square$ Identificarea unor oportunități pentru angajarea persoanelor condamnate penal;

$\square$ Dezvoltarea abilităților persoanelor condamnate penal în legătură cu găsirea unui loc de muncă;

$\square$ Informarea angajatorilor şi a mass-media în legătură cu beneficiile și costurile economice și sociale ale angajării în muncă a persoanelor condamnate penal.

\section{Beneficiari.}

$\square$ Persoane private de libertate aflate în perioada de pregătire pentru liberare;

$\square$ Persoane condamnate sub supraveghere în comunitate.

Potențiali parteneri.

$\square$ Agenții pentru ocuparea forței de muncă;

$\square$ ONG implicate în integrarea socială a grupurilor vulnerabile;

$\square$ Penitenciare;

$\square$ Servicii de probațiune;

$\square$ Servicii de asistenta socială ale autorităţilor locale.

\section{Activităti.}

1. Planificarea:

$\square$ stabilirea programului şi a responsabilităţilor.

2. Organizarea:

$\square$ identificarea surselor de finanţare; $\square$ identificarea şi stabilirea spaţiului de desfăşurare, a dotărilor şi materialelor necesare;

$\square$ invitare potenţiali angajatori;

$\square$ identificarea şi invitarea persoanelor condamnate;

$\square$ editarea materialului de informare pentru angajatori şi mass-media;

$\square$ procurarea dotărilor şi materialelor necesare şi amenajarea spaţiului;

$\square \quad$ invitarea mass-media şi mediatizarea evenimentului.

3. Desfăşurarea evenimentului:

$\square$ Informare pentru mass-media şi angajatori;

$\square$ Întâlnire între angajatori şi persoanele condamnate;

$\square$ Întâlniri ale reprezentanţilor mass-media cu persoane condamnate, angajatori şi organizatori.

4. Evaluarea rezultatelor:

$\square$ Distribuirea şi completarea chestionarelor de evaluare;

$\square$ Feed-back de la participanţi.

Rezultate aşteptate:

$\square$ persoanele condamnate participante au posibilitatea de a discuta cu reprezentanţii angajatorilor;

$\square$ persoanele condamnate pot identifica potenţiale locuri de muncă;

$\square$ angajatorii identifică posibilităţi de satisfacere a nevoii lor de forţă de muncă.

\section{Personal:}

$\square$ Consilieri de probaţiune;

$\square$ Agenţi de pază din penitenciar;

$\square$ Personal al serviciilor de educaţie şi asistenţă psihosocială din penitenciare;

$\square$ Alte persoane capabile să sprijine această activitate.

\section{Locul de desfășurare:}

$\square$ Evenimentul poate avea loc în penitenciare sau în comunitate;

$\square$ Spaţiul trebuie să fie suficient pentru numărul de participanţi şi să poată asigura condiţiile corespunzătoare de securitate;

$\square$ Este recomandat ca atunci când participă şi persoane aflate sub supraveghere în comunitate, evenimentul să se desfăşoare în comunitate.

\section{Dotarea necesară:}

$\square$ mese de lucru;

$\square$ scaune pentru angajatori şi persoane în căutarea unui loc de muncă;

$\square$ imprimante;

$\square$ televizor, video, retroproiector;

$\square$ rechizite curente;

$\square$ posibilităţi de stocare a informaţiilor şi dosarelor;

$\square$ sală de aşteptare, panouri de afișaj;

$\square$ spaţiu de protocol şi prezentare informaţii utile angajatorilor şi persoanelor prezente;

$\square$ utilităţi pentru efecte personale

$\square$ amenajări special concepute pentru accesul şi deplasarea corespunzătoare a persoanelor cu handicap;

$\square$ climat adecvat (temperatură, umiditate, luminozitate, nivel de zgomot acceptabil).

\section{Planificare.}

Succesiunea activităților:

1. Contactarea agenţilor economici prin vizite la sediul acestora, telefonic sau prin fax, pentru depistarea locurilor de muncă vacante, pentru a-i invita să participe 
şi pentru a le oferi informaţii relevante;

2. Întocmirea listei cu domeniile de activitate în care angajatorii s-au dovedit a fi interesaţi;

3. Invitaţii adresate persoanelor condamnate aflate în căutarea unui loc de muncă din evidenţa serviciilor de probaţiune şi a unităţilor penitenciare din zona în care se desfăşoară evenimentul. Invitaţiile sunt adresate personal sau în scris persoanelor care au manifestat interes sau au calificări în domeniile menţionate de angajatori;

4. Pentru pregătirea participării la eveniment, persoanele condamnate vor primi (pe lângă informaţii referitoare la ora şi locul desfăşurării acţiunii), un model de CV şi alte informaţii utile legate de modul de prezentare în faţa reprezentanţilor firmelor ofertante;

5. Întocmirea listei cu agenţii economici care au confirmat participarea;

6. Asigurarea cadrului de organizare cu facilităţi de desfăşurare: birotică, personal specializat, distribuirea chestionarelor către agenţii economici şi către solicitanţii de locuri de muncă, materiale de informare pentru angajatori şi mass-media, etc. (vezi şi dotarea necesară);

7. Chestionarele completate de către participanţi pot urmări modelele atașate;

8. Întocmirea şi afișarea vizibilă a prezentării fiecărei firme participante (denumire, domeniu de activitate în care caută forţă de muncă de muncă, meserii, nivel de calificare);

9. Mediatizarea evenimentului (presa scrisă, audio, video atât la nivel naţional cât şi local) privind locul, data şi modul de desfăşurare a bursei;

10. Întocmirea şi completarea listelor de participanţi;

11. Centralizarea de către organizatori a chestionarelor completate de participanţi;

12. Convorbire directă între angajator şi persoana în căutarea unui loc de muncă;
13. Evaluarea rezultatelor şi comunicarea acestora către organizatori, parteneri şi mass-media.

Sarcini și timpul necesar:

1. Identificarea şi centralizarea datelor referitoare la persoanele condamnate şi potenţiali angajatori permanent;

2. Convorbiri cu angajatorii şi persoane condamnate - permanent;

3. Informarea şi invitarea persoanelor în căutarea unui loc de muncă - 1 lună înainte de data evenimentului;

4. Editarea şi distribuirea invitațiilor către agenții economici, către autorităţile publice locale şi către reprezentanți ai mass-media - 5 zile;

5. Confirmarea participării agenților economici și a factorilor locali implicați în desfășurarea acesteia - 5 zile;

6. Elaborarea unei liste $\mathrm{cu}$ agenții economici participanți la bursă - 2 zile;

7. Editarea unor materiale de informare (pliante, mape, etc) - 3 zile;

8. Identificarea spaţiului corespunzător - 1 lună înainte de data de desfășurare;

9. Amenajarea spațiului - 5 zile;

10. Mediatizarea evenimentului: data, locul, programul de desfășurarea a bursei precum şi unele informații referitoare la agenții economici participanţi - 1 lună;

11. Deschiderea bursei și desfășurarea propriu-zisă a evenimentului - $1 \mathrm{zi}$;

12. Chestionarea participanţilor - pe durata desfășurării;

13. Centralizarea rezultatelor primare - la încheierea bursei;

14. Transmiterea rezultatelor bursei și mediatizarea acestora - la încheierea bursei $[1,2,4,10,11,16]$.

\section{Referințe bibliografice:}

1. BANCIU, D., RĂDULESCU, S. M., Evoluții ale delincvenței juvenile în România: cercetare și prevenire social, București : Lumina Lex, 2002., 271 p, ISBN 973-58-8484-4.

2. BELMONT, Judith. 103 activități de grup: idei de tratament și strategii practice. Tr. de S. Grădinaru. București: TREI. 2015. 221 p. ISBN 978-606-719-358-9.

3. CROWN, P. D., LIVERANT, S. Conformity under varying conditions of personal commitment // J. Abnormal and Social Psychol. 1963. V. 66.

4. DAVID, D. Dezvoltarea personală şi socială. Iaşi: Polirom, 2014. 200 p ISBN: 978-973-46- 4492-6.

5. DIȚA, M., Strategii şi metode de lucru ale asistentului social cu exdeţinuţii în vederea restabilirii legăturii cu familia. În Perspectivele integrării în spaţiul European al cercetării şi educaţiei, Materialele Conferinței științifice internationale. Cahul: US Cahul, 2015 (Tipogr. "Centrografic")., pp. 192 - 196. ISBN 978-9975-914-98-7.

6. EYSENK, H., EYSENK, M. Descifrarea comportamentului uman. București: Teora, 1998. 256 p. ISBN:973-601893-8.

7. RĂDULESCU, S. M., Devianța comportamentală și boala psihică: sociologie și psihiatrie,

8. București: Ed. Academiei Republicii Socialiste Române, 1989. ISBN 973-27-0125-0.

9. RĂDULESCU, S. M. Introducere în sociologia delincvenței juvenile : (Adolescența între normalitate şi devianţă) . București : Ed. Medicală, 1990. 163 p. ISBN 973-39-0112-1

10. RÂŞCANU, R., Psihologia comportamentului deviant. București: Universității București, 1994, 144 p. ISBN: 973-9160-18-2.

11. VÎRLAN, M., DIŢA, M., FRUNZE, O., PLĂMĂDEALĂ, V., FOCŞA, T. Programe de intervenţie psihosocială privind comportamentul deviant. Chișinău: UPS ”Ion Creangă, 2013. 97 p. ISBN 978-9975-461-52-5

12. VÎRLAN, M., DIȚA, M., Psihosociologia devianței: curs universitar, UPSC "Ion Creangă”, Chișinău: Tipogr. UPS "Ion Creangă”, 102 p. ISBN 9787-9975-46-384-5.

13. VÎRLAN, M., DIȚA, M. Rolul asistentului social în procesul de reintegrare socială a persoanelor deținute, În: Probleme ale științelor sociumane şi modernizării învățământului. Materialele Conferinței de totalizare a muncii științifice și științifico - didactice a corpului profesoral - didactic pentru anul 2018, Chișinău: UPS "Ion Creangă”, 2019. 


\section{ISBN 978-997-5337-01-4}

14. САМЫГИН, П. С. Девиантное поведение молодёжи. Учебное пособие Ростов - на Дону: Феникс, 2006. 440c. ISBN 5-222-09095-7.

15. ЗМАНОВСКАЯ, Е. В. Девиантология: Психология отклоняющегося поведения: Учебное пособие для студентов ВУЗов. 2 изд, исправл. М.: Академия, 2004. 288 с. ISBN 5-7695-1782-4.

16. http://irp.md/uploads/files/2014-06/1402576373_1242890807_ro.pdf. (Vizitat 12.03.2021) 